\title{
Purification and Properties of Alcohol Oxidase from Poria contigua
}

\author{
Stephanie BRINGER, Benno SPREY, and Hermann SAHM \\ Institut für Biotechnologie der Kernforschungsanlage Jülich GmbH \\ (Received April 11, 1979)
}

1. Alcohol oxidase (alcohol:oxygen oxidoreductase) was purified 22-fold from the brown rot fungus Poria contigua. The final enzyme preparation was homogeneous as judged by polyacrylamide gel electrophoresis, and by sedimentation in an ultracentrifuge. The molecular weight was calculated to be $610000 \pm 5000$ from sedimentation equilibrium experiments. Electrophoresis in sodium dodecylsulfate gels and electron microscopic analysis indicate that the enzyme is an octamer composed of eight probably identical subunits, each having a molecular weight of 79000 . The enzyme contains eight mol $\mathrm{FAD} / \mathrm{mol}$ as the prosthetic group.

2. This alcohol oxidase oxidizes not only methanol but also lower primary alcohols $\left(C_{2}-C_{4}\right)$, 2-propin-1-ol and formaldehyde. The apparent $K_{\mathrm{m}}$ value for methanol is $0.2 \mathrm{mM}$, and that for formaldehyde $6.1 \mathrm{mM}$. Sodium azide was found to be a competitive inhibitor with respect to methanol.

3. The enzyme from the fungus Poria contigua is immunologically different from the alcohol oxidase isolated from the methanol-utilizing yeast Candida boidinii. Furthermore antiserum raised against this enzyme did not cross-react with the alcohol oxidase from the white rot fungus Polyporus obtusus.

Evidence has been obtained that besides the well known lignin-degrading white rot fungi, brown rot fungi are also able to decompose this polymer. Previous studies have shown that the brown fungi attack the methoxyl groups more actively than the other carbons of the lignin skeleton, and oxidize them to carbon dioxide $[1,2]$. This demethylation is probably catalyzed by phenol oxidases or monooxygenases. Using phenol oxidase purified from Polyporus versicolor, Ishihara and Ishihara could measure the liberation of small amounts of methanol as a result of demethylase was isolated which required oxygen and from the fungus Xerocomus badius, a 4-veratrate demethylase was isolated which required oxygen and $\mathrm{NADH}$, and cleaved off the methoxyl groups as formaldehyde [4].

So far nothing is known about the enzymes oxidizing the $C_{1}$ compounds methanol and/or formaldehyde to carbon dioxide in brown rot fungi. Recently it has been shown that in methanol-utilizing yeasts, the methanol is successively oxidized to carbon dioxide by the enzymes alcohol oxidase, formaldehyde dehydrogenase and formate dehydrogenase [5]. Further-

Enzyme. Alcohol oxidase or alcohol:oxygen oxidoreductase (EC 1.1.3.13). more the occurrence of alcohol oxidase in several basidiomycetes was described previously [6,7]. The present paper is concerned with the purification and properties of alcohol oxidase obtained from the brown rot fungus Poria contigua, which is very active both in the demethylation of lignin and in the oxidation of the methoxyl groups to carbon dioxide. The molecular, catalytic and immunochemical properties of this enzyme are compared with alcohol oxidases from methanol-utilizing yeasts and the white rot fungus Polyporus obtusus.

\section{MATERIALS AND METHODS}

\section{Materials}

Freund's adjuvant was obtained from Calbiochem (Gießen, F.R.G.). Bathophenanthroline was bought from Serva (Heidelberg, F.R.G.). 2,2'-Azinobis(3-ethyl-benzthiazoline 6-sulfonate), peroxidase from horse-radish, and calibration proteins were purchased from Boehringer (Mannheim, F.R.G.). Ultrafilter UM 10 were obtained from Amicon (Witten, F.R.G.). Formaldehyde was prepared by heating $0.5 \mathrm{~g}$ paraformaldehyde in $5 \mathrm{ml}$ water at $100^{\circ} \mathrm{C}$ in a sealed tube for $15 \mathrm{~h}$. Antibodies against alcohol oxi- 
dase from Candida boidinii were a generous gift from Dr L. Eggeling of this institute.

\section{Organisms and Growth Conditions}

The brown rot fungi Poria contigua and Lenzites trabea were kindly supplied by Dr K. Haider (FAL Braunschweig, F.R.G.), Polyporus obtusus (ATCC no. 26733), which produces alcohol oxidase, was used as a fungus belonging to the white rot fungi [7]. The fungi were grown in $500-\mathrm{ml}$ conical flasks containing $100 \mathrm{ml}$ of the medium : $0.4 \%(\mathrm{w} / \mathrm{v})$ yeast extract, $1.0 \%$ $(\mathrm{w} / \mathrm{v})$ malt extract and $0.4 \%(\mathrm{w} / \mathrm{v})$ glucose. The flasks were inoculated by a mycelial suspension and incubated at $27^{\circ} \mathrm{C}$ on a rotary shaker $(100 \mathrm{rev} . / \mathrm{min})$ for 9 days (Poria contigua), for 15 days (Lenzites trabea) or for 20 days (Polyporus obtusus). Mycelia were harvested by filtration, washed with $50 \mathrm{mM}$ potassium phosphate buffer, $\mathrm{pH} 7.5$, and stored at $-20^{\circ} \mathrm{C}$ until required for use.

The yeasts Candida boidinii (ATCC 32 195) and Hansenula polymorpha (CBS 4732) were grown in a basal medium with $1 \%(\mathrm{v} / \mathrm{v})$ methanol as the sole carbon and energy source as described previously [8].

\section{Assay of Alcohol Oxidase}

The enzyme activity was measured at $30^{\circ} \mathrm{C}$ and with air-saturated solutions by determination of hydrogen peroxide production or oxygen consumption; both assays gave comparable results. The formation of hydrogen peroxide was determined by modification of the method of Sahm and Wagner [9]. The assay mixture consisted of : $50 \mu \mathrm{mol}$ potassium phosphate buffer, pH 7.5, $100 \mu \mathrm{mol}$ methanol, $2 \mu \mathrm{mol} 2,2^{\prime}$ azino-bis(3-ethylbenzthiazoline 6-sulfonate), 3 units of peroxidase and limiting amounts of enzyme in a total volume of $1 \mathrm{ml}$. The increase in absorbance at $420 \mathrm{~nm}$ was followed [10].

Oxygen consumption was measured in an oxygen electrode cell (Yellow Springs Instrument Co., Inc., U.S.A.). The reaction mixture was composed of $150 \mu \mathrm{mol}$ potassium phosphate buffer, $\mathrm{pH} 7.5$, $300 \mu \mathrm{mol}$ methanol and limiting amounts of enzyme in a total volume of $3 \mathrm{ml}$. One unit of alcohol oxidase activity is defined as the amount of enzyme producing $1 \mu \mathrm{mol}$ hydrogen peroxide, or consuming $1 \mu \mathrm{mol}$ oxygen per min under assay conditions.

\section{Polyacrylamide Gel Electrophoresis}

Analytical and preparative polyacrylamide gel electrophoresis were performed in $7 \%$ slab gels. The separation gels contained in a final concentration $0.375 \mathrm{M}$ Tris- $\mathrm{HCl}$ buffer, $\mathrm{pH} 8.9$, according to system 1 of Maurer [11]. The gels were stained with Coomassie brilliant blue as described by Fairbanks et al. [12]. For preparative gel electrophoresis 5-mm-thick slab gels were used as described by Sprey et al. (this institute, unpublished work). The molecular weight of the polypeptide chains was estimated according to Weber and Osborn [13]. The purified enzyme was incubated in $10 \mathrm{mM}$ sodium phosphate buffer, $\mathrm{pH} 7.0$, containing $1 \%$ sodium dodecylsulfate and $1 \% 2$-mercaptoethanol for $2 \mathrm{~h}$ at $50^{\circ} \mathrm{C}$ before the run. The following reference proteins, with their molecular weights given, were used: trypsin inhibitor from soybean, 21500 ; bovin serum albumin, 68000 ; RNA polymerase from $E$. coli and its subunits, $39000,155000,165000$ [14-16].

\section{Ultracentrifugation}

Sedimentation equilibrium ultracentrifugations were performed in a Beckman Spinco model E analytical ultracentrifuge equipped with monochromator and photoelectric scanner. The enzyme was dissolved in $10 \mathrm{mM}$ potassium phosphate buffer, pH 7.6. Protein concentration was measured by absorbance at $280 \mathrm{~nm}$.

\section{Immunological Assays}

Antibodies against alcohol oxidase were raised in a rabbit by subcutaneous injection of purified enzyme $(2.3 \mathrm{mg})$ dissolved in $1 \mathrm{ml}$ of $50 \mathrm{mM}$ potassium phosphate buffer, $\mathrm{pH} 7.5$, together with $1 \mathrm{ml}$ of Freund's complete adjuvant and $0.2 \mathrm{ml}$ of $9 \% \mathrm{NaCl}$ solution. Two following injections $(1.9 \mathrm{mg})$ were given at weekly intervals. The animal was bled from the ear vein. Serum was stored at $-20^{\circ} \mathrm{C}$.

Double immunodiffusion tests were conducted in $2 \%$ agarose gels with a $0.1 \mathrm{M}$ Tris- $\mathrm{HCl}$ buffer, $\mathrm{pH} 7.5$, containing $0.005 \%$ merthiolate [17]. Immunoelectrophoresis was carried out on agarose electrophoresis films (Corning ACI, California, U.S.A.) using a $0.05 \mathrm{M}$ barbital buffer, adjusted to $\mathrm{pH} 8.6$ with $\mathrm{HCl}$; $15 \mathrm{~V} / \mathrm{cm}$ were applied for $30 \mathrm{~min}$.

\section{Other Analytical Methods}

Protein was determined by the method of Lowry et al. [18], using bovine serum albumin as a standard. The prosthetic group (FAD) was identified in the enzyme extract after 2 -min treatment at $100^{\circ} \mathrm{C}$ by thin-layer chromatography (silica gel 60). The solvent systems were the same as described by Pazur and Kleppe [19]. The FAD in the enzyme extract was determined by measurement of the oxygen consumption using apo-D-amino acid oxidase [20]. Formaldehyde formed in the reaction mixture was assayed by the chromotropic acid reaction as described by Frisell and Mackenzie [21]. Iron analysis was performed with bathophenanthroline [22], as well as by atomic absorption and emission spectroscopy measurements. For electron microscopic analysis, the 
enzyme was applied to a carbon-coated copper grid, negatively stained with $2 \%$ uranyl acetate, and examined in a Siemens Elmiskop I electron microscope. Plates were exposed at a primary magnification of $80000 \times$. For amino acid analysis, the enzyme was hydrolyzed at $110^{\circ} \mathrm{C}$ for $20 \mathrm{~h}$ in evacuated, sealed Pyrex tubes. The hydrolyzate was analyzed in a Beckman Multichrom amino acid analyzer.

\section{RESULTS}

\section{Purification of Alcohol Oxidase}

Unless otherwise stated, all operations were carried out at $4{ }^{\circ} \mathrm{C}$.

Step 1: Crude Extract. $15 \mathrm{~g}$ (wet weight) of mycelium were suspended in $10 \mathrm{ml}$ of $50 \mathrm{mM}$ potassium phosphate buffer, $\mathrm{pH} 7.5$, and transferred to an X-press (AB Biox, Nacka, Sweden). After freezing at $-20{ }^{\circ} \mathrm{C}$ the mycelium was extruded with the hydraulic press through an orifice $0.8 \mathrm{~mm}$ in diameter. This extrusion was repeated six times, and then the crude extract was centrifuged at $48000 \times g$ for $30 \mathrm{~min}$. The resultant supernatant was used as the cell-free extract.

Step 2: Ammonium Sulfate Fractionation. Crystalline ammonium sulfate was added gradually to the cell-free extract to $55 \%$ saturation. After stirring for $2 \mathrm{~h}$, the precipitate was removed by centrifugation for $20 \mathrm{~min}$ at $48000 \times \mathrm{g}$ and discarded. Additional solid ammonium sulfate was added until $70 \%$ saturation was reached. During the precipitation procedure the temperature was $0^{\circ} \mathrm{C}$, and the $\mathrm{pH}$ was maintained at 7.5 with a $10 \%$ ammonium hydroxide. The precipitate was collected by centrifugation for $20 \mathrm{~min}$ at $48000 \times \mathrm{g}$, and dissolved in $10 \mathrm{mM}$ potassium phosphate buffer, $\mathrm{pH}$ 7.5. This fraction was dialyzed for $16 \mathrm{~h}$ against three changes of the same buffer.

Step 3a: Preparative Polyacrylamide Gel Electrophoresis. 5-ml aliquots of the enzyme solution obtained in the previous step were applied to slab gels and electrophoresis was carried out overnight. After separation, the enzyme was visible as a yellow band in the upper third of the gel. This zone was cut out, frozen, and extruded through an X-press. From the disintegrated gel, the enzyme was eluted with water by stirring overnight. The polyacrylamide was removed by centrif- ugation and the extraction procedure was repeated. The combined supernatant fractions were dialyzed against $50 \mathrm{mM}$ potassium phosphate buffer, pH 7.5 and concentrated by ultrafiltration. Data of a typical purification experiment are presented in Table 1. The purified enzyme gave a single band after disc gel electrophoresis, and sedimented as a single component in the ultracentrifuge.

Step 3b: Sucrose Gradient Centrifugation. Since the molecular weights of the alcohol oxidases isolated from yeasts were found to be very high, we also tried to isolate the enzyme by sucrose density gradient centrifugation as described by Goldthwaite and Bogorad [23]. Samples of $0.5 \mathrm{ml}(4.0-4.5 \mathrm{mg}$ protein) of the enzyme solution obtained in step 1 were layered on a $11.0-\mathrm{ml}$ linear sucrose gradient in an SW-41 cellulose nitrate centrifuge tube. The sucrose concentration ranged from 0.2 to $0.7 \mathrm{M}(7-24 \% \mathrm{w} / \mathrm{v})$, and it was buffered at $\mathrm{pH} 7.5$ with $0.02 \mathrm{M}$ Tris-sulfate. The gradients were centrifuged for $17 \mathrm{~h}$ in an SW-41 rotor at $28000 \mathrm{rev} . / \mathrm{min}$. After centrifugation, the gradient was fractionated from the top by pumping $1.0 \mathrm{M}$ sucrose $(34 \% \mathrm{w} / \mathrm{v})$ into the bottom of the tube. The absorption of the gradient at $280 \mathrm{~nm}$ was monitored and the fractions were collected. A typical separation of alcohol oxidase on the sucrose gradient used is shown in Fig. 1. The major absorption peak in the middle of the gradient corresponded with alcohol oxidase activity. These fractions were dialyzed against $50 \mathrm{mM}$ potassium phosphate buffer, $\mathrm{pH}$ 7.5. The purity of alcohol oxidase from the sucrose gradient peak was established by analytical polyacrylamide gel electrophoresis, which gave a single band. Furthermore, this preparation showed the same specific activity as the enzyme obtained in step $3 a$. When the purified enzyme $(4-5 \mathrm{mg} / \mathrm{ml})$ was stored in the presence of the antimicrobial agent sodium azide $(0.01 \%$ in $50 \mathrm{mM}$ potassium phosphate buffer, $\mathrm{pH} 7.5$ ) at $4^{\circ} \mathrm{C}$ no decay of activity was observed over a period of two weeks. Freezing at $-20^{\circ} \mathrm{C}$ and thawing resulted in a decrease of enzyme activity of about $25 \%$.

\section{Molecular Weight and Subunit Structure}

The molecular weight of the alcohol oxidase was determined by the sedimentation equilibrium method.

Table 1. Purification of alcohol oxidase from Poria contigua

One unit (U) of enzyme is the amount that catalyzes the production of $1 \mu \mathrm{mol} \mathrm{H}_{2} \mathrm{O}_{2} / \mathrm{min}$

\begin{tabular}{lcccccc}
\hline Step & Volume & Protein & $\begin{array}{l}\text { Total } \\
\text { activity }\end{array}$ & $\begin{array}{l}\text { Specific } \\
\text { activity }\end{array}$ & Yield & Purification \\
\hline & $\mathrm{ml}$ & $\mathrm{mg}$ & $\mathrm{U}$ & $\mathrm{U} / \mathrm{mg}$ & $\%$ & - fold \\
Cell-free extract & 250 & 1554 & 1476 & 0.95 & 100 & 1 \\
$\left(\mathrm{NH}_{4}\right)_{2} \mathrm{SO}_{4}$ fraction, $55-70 \%$ saturation & 19 & 167 & 1144 & 6.85 & 77.5 & 7.2 \\
Prep. polyacrylamide electrophoresis & 35 & 34 & 702 & 20.67 & 47.6 & 21.8 \\
\hline
\end{tabular}




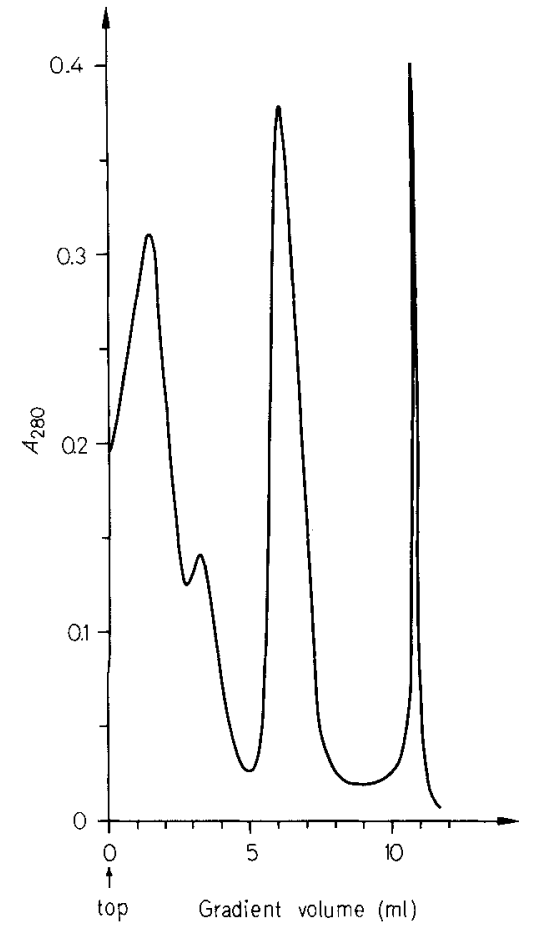

Fig. 1. Elution profile of a sucrose gradient for the purification of alcohol oxidase. The enzyme was eluted between 5.0 and $8.0 \mathrm{ml}$ of the gradient volume

The enzyme was sedimented to equilibrium at 4000 $\mathrm{rev} . / \mathrm{min}$ and $5{ }^{\circ} \mathrm{C}$. The molecular weight was obtained from semilogarithmic plots of the absorbance versus the square of the radial distance according to Svedberg and Pedersen [24]. Assuming a partial specific volume of $0.75 \mathrm{~cm}^{3} / \mathrm{g}$, a molecular weight of $610000 \pm 5000$ was calculated from the data. The sedimentation coefficient $s_{\mathrm{w}, 20}=21.5 \pm 0.1 \mathrm{~S}$ was measured by analyzing the sedimentation of the enzyme at $30000 \mathrm{rev}$./ min at $18.7^{\circ} \mathrm{C}$. When the enzyme was subjected to gel electrophoresis in the presence of sodium dodecylsulfate, only one protein band was observed. By comparing the relative mobility of this band to that of other proteins of known molecular weights, a molecular weight of 79000 was calculated. This is approximately one eighth the value found under native conditions by sedimentation equilibrium. Therefore it seems that the alcohol oxidase from Poria contigua is an octamer composed of eight probably identical subunits.

This octameric subunit model was confirmed by electron microscopic analysis. Fig. 2 shows an electron micrograph of a negatively stained preparation of alcohol oxidase from Poria contigua. The molecule appears to be either bisectioned or tetrad, depending on its orientation in the image plane. From these micrographs it can be concluded that the complete structure is an octad aggregate composed of two tetragons face-to-face as reported previously for the alcohol

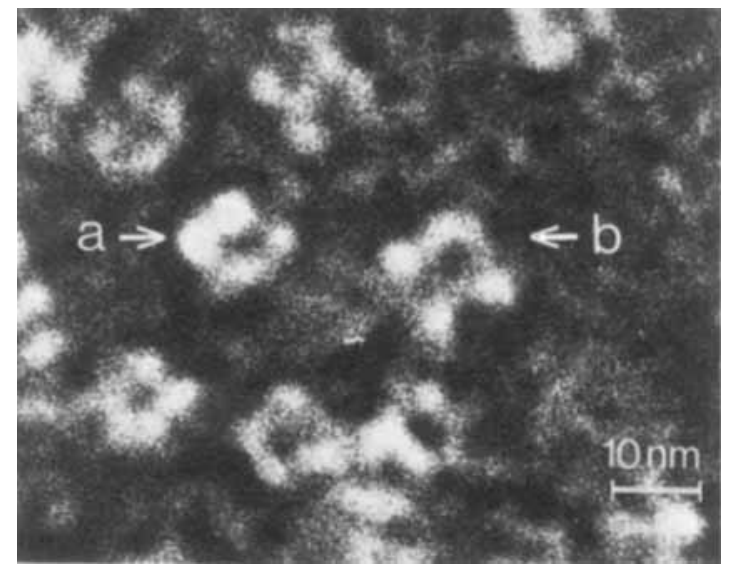

Fig. 2. Electron micrograph of the alcohol oxidase from Poria contigua. The enzyme was negatively stained with uranyl acetate. (a) Alcohol oxidase molecule appearing bisectioned; (b) molecule appearing tetrad

oxidases from the yeasts Kloeckera sp. and Hansenula polymorpha [25].

\section{Absorption Spectrum and Identification of the Prosthetic Group}

The native enzyme from Poria contigua has absorption peaks in the visible spectrum at 330 and $455 \mathrm{~nm}$, with a shoulder at $380 \mathrm{~nm}$ (Fig. 3). Thus this spectrum pattern is different from that of the alcohol oxidases from the yeasts described previously $[9,26]$. In order to exclude that the different techniques for the isolation of the enzymes have an influence on the absorption spectra, the alcohol oxidase from the methanol-utilizing yeast Candida boidinii was also purified by preparative polyacrylamide gel electrophoresis. This enzyme preparation showed an absorption spectrum which was very similar to those reported for the enzymes from yeasts with maxima at 370 and $467 \mathrm{~nm}$ and a shoulder at $395 \mathrm{~nm}$ (Fig. 3).

Since the absorption spectrum of the alcohol oxidase from Poria contigua is similar to that reported for ferroflavoproteins [27], the enzyme was examined for flavin and iron content. The heated enzyme extract showed the typical absorption spectrum of flavin which was identified as FAD by thin-layer chromatography as described in Materials and Methods. The FAD content of the enzyme was calculated as $8.02 \mathrm{~mol} /$ mol enzyme. However, no iron was detected by the bathophenanthroline method and less than $1 \mathrm{~mol}$ iron/mol enzyme were found by atomic absorption and emission spectroscopy measurements. Since no experiments were made with respect to the occurrence of other metals in the enzyme the absorption spectrum cannot be explained at present. 


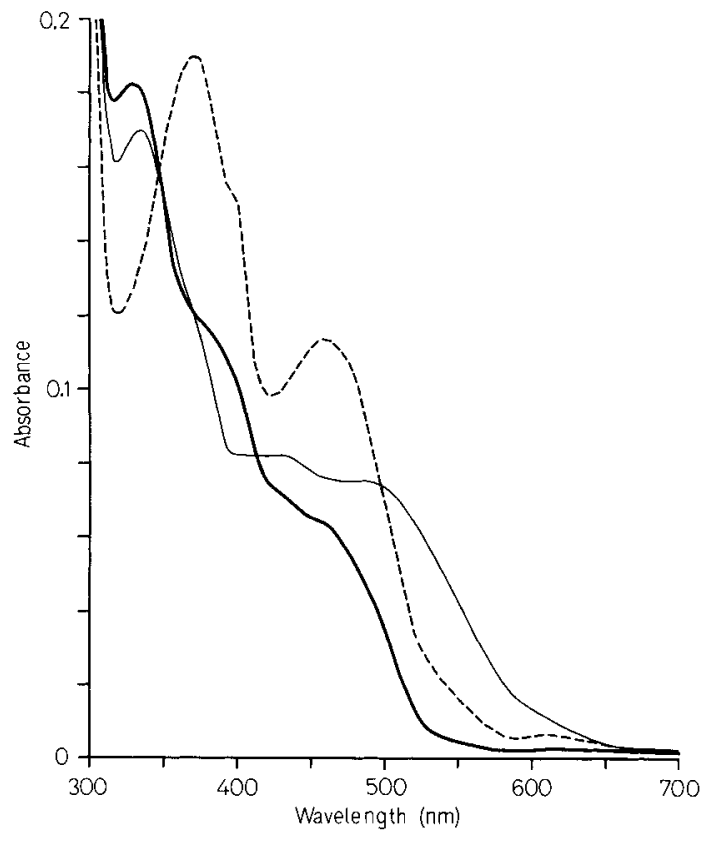

Fig. 3. Absorption spectra of alcohol oxidase from Poria contigua (-) and Candida boidinii (---). Concentrations were $2.0 \mathrm{mg} /$ $\mathrm{ml}$ of the Poria enzyme and $1.6 \mathrm{mg} / \mathrm{ml}$ of the Candida enzyme. The alcohol oxidases were dissolved in $100 \mathrm{mM}$ sodium phosphate buffer, $\mathrm{pH}$ 7.5. Absorption spectrum of alcohol oxidase from Poria contigua in the presence of $1.5 \mathrm{mM}$ sodium azide (- ${ }_{-}$) is also shown

\section{Substrate Specificity}

The enzyme from Poria contigua has a broad substrate specificity. It catalyzes the oxidation of different short-chain primary aliphatic alcohols. The apparent Michaelis constants and apparent $V$ values for various alcohols indicate that methanol is the best substrate, and that reactivity decreases as the chain length of the alcohols increases (Table 2). Oxidation of formaldehyde by alcohol oxidase is presumably due to the fact that in aqueous solution, formaldehyde is predominantly hydrated $(99 \%)$, and presumably appears as an analogue of methanol for the alcohol oxidase. Isopropyl alcohol, benzyl alcohol and 2-mercaptoethanol were oxidized only at high concentrations, while 2-propin-1-ol served as a good substrate.

The stoichiometry of methanol oxidation by this enzyme is in accordance with that reported for alcohol oxidases from yeasts $[9,29]$ and can be described by the equation:

$$
\mathrm{CH}_{3} \mathrm{OH}+\mathrm{O}_{2} \rightarrow \mathrm{HCHO}+\mathrm{H}_{2} \mathrm{O}_{2} \text {. }
$$

\section{Effect of Inhibitors on the Enzyme Activity}

The effect of various reagents on the oxidation of methanol by the enzyme was studied without preincubation. The enzyme activity was completely inhibited by the sulfhydryl reagent $p$-chloromercuribenzoate
Table 2. Substrate specificity of alcohol oxidase from Poria contigua The oxidation of 2-mercaptoethanol was assayed in the oxygen electrode; with all other substrates the liberation of hydrogen peroxide was measured. Apparent $K_{\mathrm{m}}$ and $V$ values were determined from Lineweaver-Burk plots [28]. n.d. = not determined

\begin{tabular}{lll}
\hline Substrate & \multicolumn{2}{c}{ Apparent value of } \\
\cline { 2 - 3 } & $K_{\mathbf{m}}$ & $V$ \\
\hline & $\mathrm{mM}$ & $\mu$ mol $\mathrm{H}_{2} \mathrm{O}_{2} \cdot \mathrm{min}^{-1}$ \\
& & $($ nmol protein) \\
& & 12.8 \\
Methanol & 0.2 & 12.0 \\
Ethanol & 1.0 & 9.4 \\
1-Propanol & 8.3 & n.d. \\
1-Butanol & 21.3 & n.d. \\
Isopropyl alcohol & 25.0 & 7.5 \\
2-Propin-1-ol & 3.2 & 1.9 \\
Formaldehyde & 6.1 & n.d. \\
2-Mercaptoethanol & 27.2 & \\
\hline
\end{tabular}

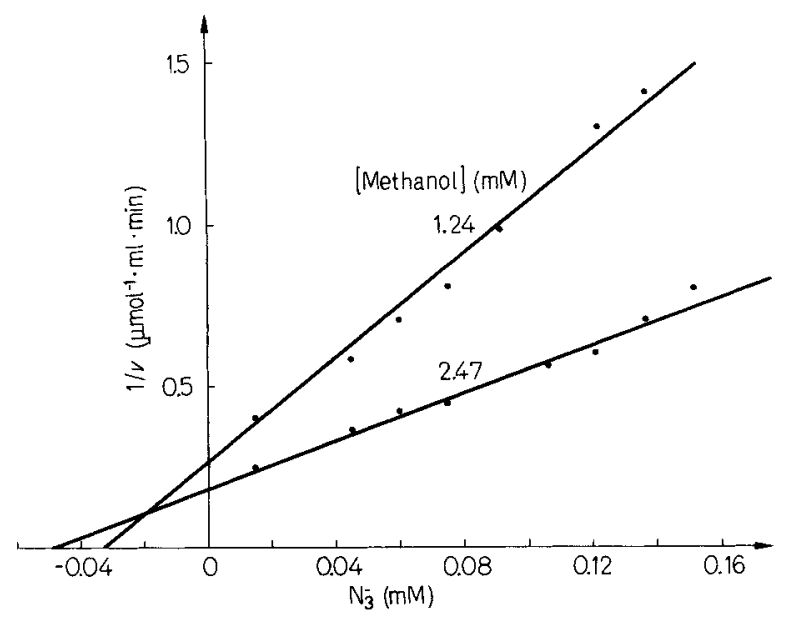

Fig. 4. Dixon plot for alcohol oxidase from Poria contigua with methanol as a substrate and sodium azide as a competitive inhibitor with $a \mathrm{~K}_{i}$ value of $0.02 \mathrm{mM}[30]$. Enzyme activity was measured by determination of hydrogen peroxide formed under standard assay conditions

(1 $\mathrm{mM})$. This result indicates that a cysteine residue in the protein is essential for the activity, or to maintain the proper structure of the enzyme. Furthermore, sodium azide was found to be a strong inhibitor of the enzymatic reaction, while sodium cyanide had no effect on the enzyme activity in $1 \mathrm{mM}$ concentration. As shown in Fig. 4, the inhibition of azide is competitive with methanol. The $K_{\mathrm{i}}$ value was determined from a Dixon plot and found to be $0.02 \mathrm{mM}$. In the absence of methanol, the addition of azide $(1.5 \mathrm{mM})$ to the enzyme solution caused a change of the colour from yellow to red (Fig. 3). Van Dijken isolated a red and a yellow alcohol oxidase from the yeast Hansenula polymorpha depending on the growth conditions of the organism; despite the differences in their oxidized 


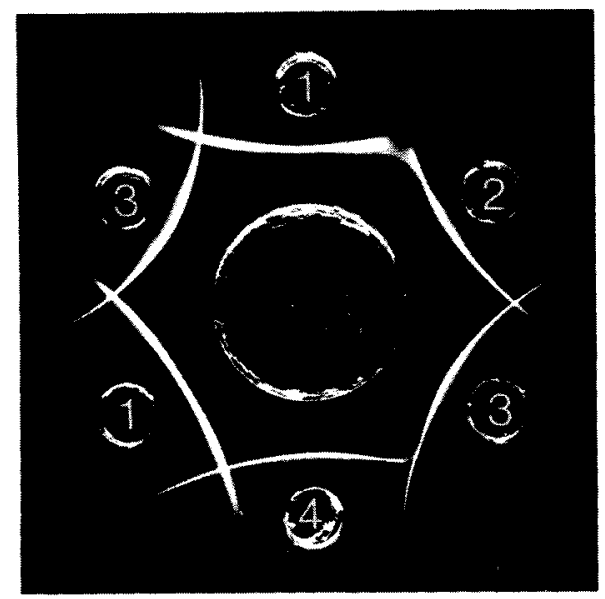

Fig.5. Double immunodiffusion tests with alcohol oxidase from the fungi Poria contigua (1) and Lenzites trabea (2) and the yeasts Candida boidinii (3) and Hansenula polymorpha (cell-free extract, 4 ). The central well contained equal amounts of antisera against the alcohol oxidase from Poria contigua and from Canida boidinii

Table 3. Comparison of amino acid composition of the alcohol oxidases from Poria contigua and from the methanol-utitizing yeasts Hansenula polymorpha and Kloeckera $s p$. n.d. = not determined

\begin{tabular}{llll}
\hline Amino acid & $\begin{array}{l}\text { Poria } \\
\text { contigua }\end{array}$ & $\begin{array}{l}\text { Hansenula } \\
\text { polymorpha } \\
{[25]}\end{array}$ & $\begin{array}{l}\text { Kloeckera sp. } \\
{[25]}\end{array}$ \\
& residue/79000 $\mathrm{g}$ & residue/83000 g \\
\cline { 2 - 3 } Lysine & 39 & 39 & 44 \\
Histidine & 22 & 21 & 19 \\
Arginine & 33 & 39 & 38 \\
Aspartic acid & 74 & 106 & 94 \\
Threonine & 43 & 50 & 43 \\
Serine & 29 & 56 & 53 \\
Glutamic acid & 46 & 64 & 73 \\
Proline & 43 & 50 & 47 \\
Glycine & 82 & 64 & 66 \\
Alanine & 51 & 41 & 48 \\
Valine & 45 & 35 & 29 \\
Methionine & 11 & 12 & 13 \\
Isoleucine & 28 & 29 & 24 \\
Leucine & 48 & 52 & 48 \\
Tyrosine & 22 & 31 & 38 \\
Phenylalanine & 17 & 36 & 32 \\
Half-cystine & n.d. & 15 & 13 \\
Tryptophan & n.d. & 11 & 17 \\
\hline
\end{tabular}

absorption spectra the kinetic properties of the two enzyme preparations were very similar [31].

\section{Serological Properties}

The ability of antiserum prepared against the purified alcohol oxidase of Poria contigua to crossreact with alcohol oxidases from fungi and methanolutilizing yeasts was determined by immunodiffusion techniques. Precipitin bands were formed with alcohol oxidases derived from the two representatives of brown rot fungi: Lenzites trabea and Poria contigua; spurs were not formed when the enzymes from these organisms were placed in neighbouring wells (Fig.5). Thus these organisms appear to form immunologically similar enzymes. In contrast, alcohol oxidases from the white rot fungus Polyporus obtusus, and from the methanol-utilizing yeasts Candida boidinii and Hansenula polymorpha formed no precipitin bands under these conditions. Antiserum against the purified alcohol oxidase from the yeast Candida boidinii showed precipitin bands against the enzymes from yeasts, but no bands against the enzymes from fungi. Thus the alcohol oxidases from the brown rot fungi are immunologically different from the enzyme of the white rot fungus, as well as from the enzymes purified from methanol-utilizing yeasts. This result was confirmed by immunoelectrophoretical experiments (Fig.6). Furthermore, the amino acid analysis of the alcohol oxidase from Poria contigua shows that the enzyme contains considerably more glycine and less aspartic acid, glutamic acid, serine and phenylalanine than the yeast enzymes determined by Kato et al. (Table 3 ).

\section{DISCUSSION}

Several reports have shown that in methanolutilizing microorganisms, two quite different groups of methanol-oxidizing enzymes exist. Bacteria grown on methanol possess an alcohol dehydrogenase. This enzyme activity is dependent on the presence of ammonium ions, and requires phenanzine methosulfate as a primary hydrogen acceptor [32]. In methanolassimilating yeasts, methanol is oxidized by an alcohol oxidase which is a flavoprotein containing FAD as prosthetic group [5]. A similar enzyme was also isolated from a basidiomycete [6].

Our results demonstrate that the enzyme purified from the brown rot fungus Poria contigua is similar to the alcohol oxidases from methanol-utilizing yeasts, and from a basidiomycete, in several aspects (Table 4). (a) Enzyme activity is dependent on the presence of oxygen in the reaction mixtures. (b) The enzyme has a molecular weight of about 600000 and is composed of eight probably identical subunits with a molecular weight of about 80000 . (c) The apparent $K_{\mathrm{m}}$ for methanol is $0.2 \mathrm{mM}$, similar to the value obtained for the enzyme from Hansenula polymorpha [25]. (d) The enzyme is not specific for methanol; it also catalyzed the oxidation of lower primary aliphatic alcohols and of formaldehyde.

The purified enzyme from Poria contigua differs from other alcohol oxidases, listed in Table 4 , in its absorption spectrum. While the other enzymes have absorption maxima at 375 and $460 \mathrm{~nm}$ and a shoulder 


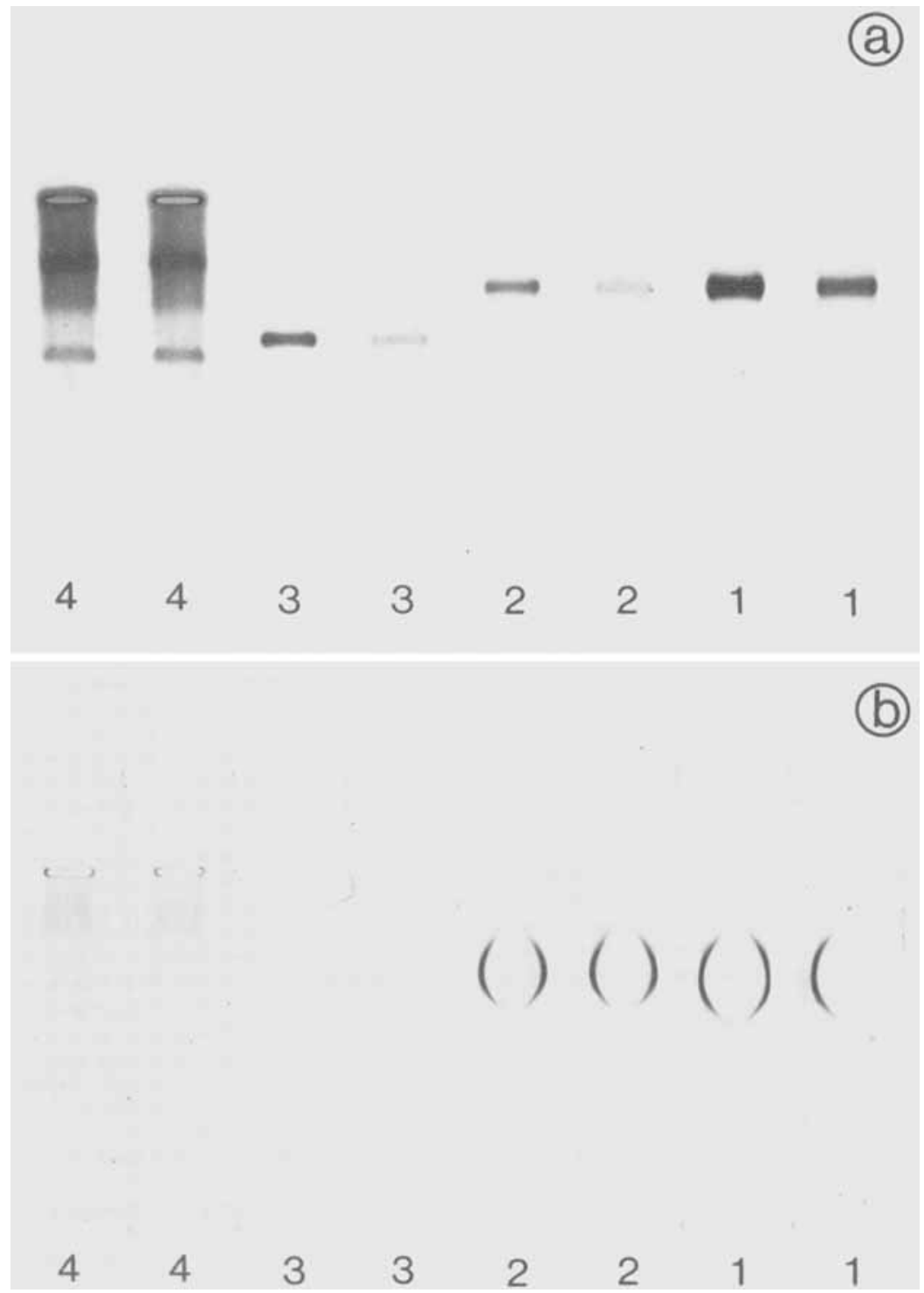

Fig. 6. Immunoelectrophoresis of alcohol oxidases from fungi and yeasts. (1) Poria contigua; (2) Lenzites trabea; (3) Candida boidinii; (4) Hansenula polymorpha, cell-free extract. (a) Agarose electrophoresis with subsequent staining of protein bands. (b) Agarose electrophoresis followed by immunodiffusion with antiserum against alcohol oxidase from Poria contigua

Table 4. Comparison of properties of purified alcohol oxidases from yeasts and fungi

\begin{tabular}{|c|c|c|c|c|c|c|}
\hline Organism & $\begin{array}{l}\text { Molecular } \\
\text { weight }\end{array}$ & $\begin{array}{l}\text { Molecular } \\
\text { weight } \\
\text { of subunits }\end{array}$ & $\begin{array}{l}K_{\mathrm{m}} \\
\text { for } \\
\mathrm{CH}_{3} \mathrm{OH}\end{array}$ & $\lambda_{\max }$ & $\begin{array}{l}\text { Prosthetic } \\
\text { group }\end{array}$ & $\begin{array}{l}\text { Substrate } \\
\text { specificity }\end{array}$ \\
\hline & & & $\mathrm{mM}$ & $\mathrm{nm}$ & & \\
\hline \multicolumn{7}{|l|}{ 1. Yeasts: } \\
\hline Hansenula polymorpha $[31,33]$ & 616000 & 77000 & 1.3 & $380,395,450$ & FAD & \multirow{4}{*}{$\begin{array}{l}\text { short-chain primary } \\
\text { alcohols and formaldehyde }\end{array}$} \\
\hline Hansemula polymorpha [25] & 669000 & 83000 & 0.23 & n.d. & FAD & \\
\hline Kloeckera sp. $[25,26]$ & 673000 & 83000 & 0.44 & $373,392,461$ & FAD & \\
\hline Candida boidinii [9] & 600000 & 74000 & 2.0 & 372,460 & FAD & \\
\hline \multicolumn{7}{|l|}{ 2. Fungi: } \\
\hline Polyporus sp. $[6,34]$ & $>300000$ & 85000 & 1.52 & n.d. & FAD & \multirow{2}{*}{$\begin{array}{l}\text { short-chain primary } \\
\text { alcohols and formaldehyde }\end{array}$} \\
\hline Paria contigua & 610000 & 79000 & 0.2 & $330,380,455$ & FAD & \\
\hline
\end{tabular}


at $395 \mathrm{~nm}$, the enzyme purified from Poria contigua has maxima at 330,380 and $455 \mathrm{~nm}$, which may result from the different amino acid composition, as compared with Hansenula polymorpha and Kloeckera sp.

Immunological studies provide further evidence that the alcohol oxidase from yeasts and from fungi differ in their primary structure. Antiserum prepared against the purified alcohol oxidase from the brown rot fungus Poria contigua cross-reacted only with the enzyme from the brown rot fungus Lenzites trabea, but not with the enzymes from yeasts. On the other hand, antiserum prepared against alcohol oxidase from the methanol-utilizing yeast Candida boidinii cross-reacted with the enzyme from the yeast Hansenula polymorpha, but not with the enzymes from the two fungi. It might be very interesting for taxonomical studies to note that the alcohol oxidase from the white rot fungus Polyporus obtusus gave no preciptin band with these two antisera.

It seems probable that the alcohol oxidase is a common mechanism for the oxidation of methanol in methanol-utilizing yeasts, and in lignin-degrading basidiomycetes. This enzyme is also able to oxidize formaldehyde to formate since this $C_{1}$ compound is almost fully hydrated in aqueous solution. However, in methanol-utilizing yeasts, it seems that alcohol oxidase is not involved in the oxidation of formaldehyde in vivo, but that an NAD-linked formaldehyde dehydrogenase catalyses this reaction. It will be of great interest to study whether formaldehyde is oxidized in lignin-decomposing basidiomycetes by alcohol oxidase or by an NAD-dependent formaldehyde dehydrogenase, which may be coupled with the energy reproduction system.

We thank Prof. Buse (RWTH Aachen) for the amino acid analysis, Dr Floßdorf (GBF, Braunschweig) for the ultracentrifugation studies, $\mathrm{Mr}$ Bochem for the electron microscopic analysis, Dr Wolff (Zentralabteilung für chemische Analysen) for the atomic absorption and emission spectroscopy measurements.

\section{REFERENCES}

1. Kirk, T. K. \& Adler, E. (1970) Acta Chem. Scand. 24, 33793390.
2. Ander, P. \& Eriksson, K.-E. (1978) Prog. Ind. Microbiol. 14, $1-59$.

3. Ishihara, T. \& Ishihara, M. (1975) J. Jap. Wood Res. Soc. 21, $323-325$.

4. Paszczyński, A. \& Trojanowski, J. (1977) Microbios, 18, 111 121.

5. Sahm, H. (1977) Adv. Biochem. Eng. 6, 77-103.

6. Janssen, F. W. \& Ruelius, H. W. (1968) Biochim. Biophys. Acta, 151, 330-342.

7. Kerwin, R. M. \& Ruelius, H. W. (1969) Appl. Microbiol. 17, $347-351$

8. Sahm, H. \& Wagner, F. (1972) Arch. Microbiol. 84, 29-42.

9. Sahm, H. \& Wagner, F. (1973) Eur. J. Biochem. 36, 250-256

10. Wahlefeld, A. W. (1971) Quad. Sclavo Diagn. 7, 232-242.

11. Mauer, H. R. (1971) Disc Electrophoresis, 2nd edn, p. 44, de Gruyter, Berlin, New York.

12. Fairbanks, G., Steck, T. L. \& Wallach, D. F. H. (1971) Biochemistry, 10, 2606-2616.

13. Weber, K. \& Osborn, M. (1969) J. Biol. Chem. 244, 4406-4412.

14. Wu, Y. V. \& Scheraga, H. A. (1962) Biochemistry, $1,698-705$.

15. Varsel, C., Nuwayser, E. S. \& Richard, A. J. (1970) Biochim. Biophys. Acta, 200, 414-417.

16. Burgess, R. R. (1969) J. Biol. Chem. 244, 6168-6176.

17. Stollar, D. \& Levine, L. (1963) Methods Enzymol. 6, 848-854.

18. Lowry, O. H., Rosebrough, N. J., Farr, A. L. \& Randall, R. J. (1951) J. Biol. Chem. 193, 265-275.

19. Pazur, J. H. \& Kleppe, K. (1964) Biochemistry, 2, 578- 583.

20. Massey, V. \& Swoboda, B. E. P. (1963) Biochem. Z. 338 , $474-484$.

21. Frisell, W. R. \& Mackenzie, G. G. (1958) Methods Biochem. Anal. 6, 63-77.

22. Doeg, K. A. \& Ziegler, D. M. (1962) Arch. Biochem. Biophys. $97,37-40$

23. Goldthwaite, J. J. \& Bogorad, L. (1971) Anal. Biochem. 4l, $57-66$.

24. Svedberg, T. \& Pedersen, K. O. (1959) The Ultracentrifuge, p. 48, Clarendon Press, Oxford.

25. Kato, N., Omori, Y., Tani, Y. \& Ogata, K. (1976) Eur. J. Biochem. 64, 341-350.

26. Tani, Y., Miya, T. \& Ogata, K. (1972) Agr. Biol. Chem. 36, $76-83$.

27. Komai, H., Massey, V. \& Palmer, G. (1969) J. Biol. Chem. 244, $1692-1700$.

28. Lineweaver, H. \& Burk, D. (1934) J. Am. Chem. Soc. 56, $658-666$.

29. Tani, Y., Miya, T., Nishikawa, H. \& Ogata, K. (1972) Agr. Biol. Chem. 36, $68-75$.

30. Dixon, M. (1953) Biochem. J. 55, 170-171.

31. van Dijken, J. P. (1976) Ph.D. Thesis, University of Groningen, Holland.

32. Anthony, C. \& Zatman, L. J. (1967) Biochem. J. 104, 960-969.

33. van Dijken, J. P., Otto, R. \& Harder, W. (1976) Arch. Microbiol. $111,137-144$.

34. Janssen, F. W., Kerwin, R. M. \& Ruelius, H. W. (1965) Biochem. Biophys. Res. Commun. 20, 630-634.

S. Bringer, B. Sprey, and H. Sahm, Institut für Biotechnologie der Kernforschungsanlage Jülich GmbH,

Postfach 1913, D-5170 Jülich, Federal Republic of Germany 